\title{
The polyol pathway and glucose 6-phosphate in human endothelial cells cultured in high glucose concentrations
}

\author{
${ }^{1}$ M.Lorenzi, ${ }^{1}$ S. Toledo, ${ }^{2}$ G. R. Boss, ${ }^{1}$ M. J.Lane and ${ }^{1}$ D. F. Montisano \\ Department of Medicine, ${ }^{1}$ Divisions of Endocrinology and Metabolism and \\ ${ }^{2}$ General Medicine, University of California Sān Diego, La Jolla, California, USA
}

\begin{abstract}
Summary. In an attempt to identify the mechanisms underlying the ill effects of high glucose previously described in cultured human endothelial cells, we have investigated in these cells the activity of the polyol pathway and accumulation of glucose 6-phosphate, a powerful agent of non-enzymatic glycosylation. Sorbitol accumulation varied among different batches of cells (primary cultures). In presence of $5 \mathrm{mmol} / 1$ glucose the cellular sorbitol content ranged from 0.04 to $0.12 \mathrm{nmol} / 10^{6}$ cells. When cells were exposed to $20 \mathrm{mmol} / 1$ glucose the sorbitol content increased by 2 - to 3-fold to concentrations of $0.08-0.38 \mathrm{nmol} / 10^{6}$ cells $(p<0.01)$. Addition to the culture medium of $100 \mu \mathrm{mol} / 1$ Sorbinil, an inhibitor of aldose reductase, resulted in a substantial inhibition of sorbitol accumulation throughout the 14 days in culture, but the degree of inhibition varied inversely with the duration of cell exposure to high glucose ( $70 \%$ inhibition in cells exposed to
\end{abstract}

high glucose and Sorbinil for 1-3 days versus $14 \%$ inhibition in cells exposed for 14 days, $p<0.01$ ). Sorbinil treatment failed to improve even slightly the abnormalities in cellular replication induced by high glucose. The cellular content of glucose 6-phosphate was augmented 3-fold by exposure to $20 \mathrm{mmol} / 1$ glucose $(p<0.001)$. In conjunction with other studies these results indicate that in this model the polyol pathway is not an osmotically or metabolically important mechanism of glucotoxicity, and that the inhibitory activity of Sorbinil on the polyol pathway of human tissues may be a function of their length of exposure to hyperglycaemia. The consequences of intracellular accumulation of glucose 6-phosphate await investigation.

Key words: Diabetes, angiopathy, endothelial cells, glucose, sorbitol, glucose 6-phosphate, aldose reductase, Sorbinil.
While it is well established that the morphology [1, 2], functional integrity $[1,3,4]$ and even survival $[5,6]$ of vascular endothelium are jeopardized in diabetes, the mechanisms responsible for such degenerative changes are still poorly defined. A role for toxic effects of sustained hyperglycaemia is suggested by the recent demonstration that in vitro exposure of endothelial cells to high glucose levels results in accelerated death, decreased replication and signs of DNA damage [7-9].

There are at least three recognized mechanisms whereby the chronically elevated ambient glucose characteristic of diabetes may affect tissue function and structure: enhanced activity of the polyol pathway $[10,11]$, accelerated nonenzymatic glycosylation [12] and protracted hypertonicity [13]. Although the replicative delay induced in human endothelial cells by high glucose can to some extent be mimicked by increasing medium osmolarity with mannitol, the magnitude of the mannitol effect is much less than that observed with equimolar glucose [7]. Therefore, effects specific to the glucose molecule itself must be advocated. In the present study we have investigated whether the polyol pathway plays a role in mediating the replicative abnormalities of human endothelial cells cultured in high glucose and whether these cells accumulate glucose 6-phosphate, which is a most potent effector of nonenzymatic glycosylation $[14,15]$.

\section{Materials and methods}

\section{Cell culture}

Primary cultures of endothelial cells were prepared from human umbilical veins as previously described $[7,16]$. For proliferation experiments, cells were seeded at a density of $1 \times 10^{5}$ in $35 \mathrm{~mm}$ dishes (Falcon, Oxnard, Calif, USA); for metabolic measurements cells were seeded at $4 \times 10^{5}$ in $60 \mathrm{~mm}$ dishes (Falcon). The growth medium was Medium 199 (Gibco, Grand Island, NY, USA), supplemented with glutamine $(2 \mathrm{mmol} / 1)$, Hepes buffer $(17.5 \mathrm{mmol} / 1), 10 \mathrm{ng} / \mathrm{ml}$ epidermal growth factor (EGF culture grade, Collaborative Research Inc., Lexington, Mass, USA) and $14 \%$ heat-inactivated pooled human serum. Incubation volumes were $2 \mathrm{ml}$ for $35 \mathrm{~mm}$ dishes and $4 \mathrm{ml}$ for $60 \mathrm{~mm}$ dishes. 
Cultures were incubated at $37^{\circ} \mathrm{C}$ in a humidified $5 \% \mathrm{CO}_{2}-95 \%$ air atmosphere and all media were filtered and supplemented with penicillin $(50 \mathrm{U} / \mathrm{ml})$, streptomycin $(50 \mu \mathrm{g} / \mathrm{ml})$ and fungizone $(0.25 \mu \mathrm{g} / \mathrm{ml})$ purchased from Irvine Scientific, Santa Ana, Calif, USA. Media were changed every third day. At regular intervals, the endothelial cell monolayers were tested with FITC-conjugated goat anti-factor VIII related antigen antibodies (Atlantic Antibodies, Scarborough, Me, USA) and always found to be brightly and uniformly stained. The $\mathrm{pH}$ of all incubated cultures varied between 7.2 and 7.35 .

To study the effects of high glucose concentrations the growth medium was supplemented with D-glucose (Mallinckrodt, Inc., Paris, Ky, USA) to achieve a final concentration of $20 \mathrm{mmol} / 1$. Exposure to high glucose was started the day after plating or at the indicated times before cell harvest. Glucose concentration in control medium was $5 \mathrm{mmol} / \mathrm{l}$.

In experiments addressing the effect of aldose-reductase inhibition on polyol accumulation and endothelial cell proliferation, Sorbinil (kindly provided by Pfizer Research, Groton, Conn, USA) was added to the growth medium in concentrations of 2, 4, 10 and $100 \mu \mathrm{mol} / 1$. Additions were performed either the day after plating and renewed at every medium change, or at the indicated times prior to cell harvest. Sorbinil was suspended in normal saline and solubilized by sonication after titrating to $\mathrm{pH} 9.5$ with $0.1 \mathrm{~N} \mathrm{NaOH}$. The solution was then back titrated to $\mathrm{pH} 7.4$ with $0.1 \mathrm{~N} \mathrm{HCl}$. The low concentrations of Sorbinil (2-10 $\mu \mathrm{mol} / 1)$ were chosen on the basis of the $\mathrm{IC}_{50}$ of this compound on human placenta aldose reductase [17]; the $100 \mu \mathrm{mol} / 1$ concentration was employed after witnessing the ineffectiveness of the lower concentrations. The stability of Sorbinil in the tissue culture medium was checked by testing the effect of $100 \mu \mathrm{mol} / 1$ Sorbinil, incubated with endothelial cells for 3 days in presence of $20 \mathrm{mmol} / 1$ glucose, on the accumulation of sorbitol by human erythrocytes.

\section{Measurements}

In proliferation experiments addressing whether treatment with Sorbinil would prevent or reduce the proliferative delay induced by $20 \mathrm{mmol} / \mathrm{l}$ glucose, cell counts were performed every other day from day 4 to day $12-14$ in culture. The procedures employed have been previously described [7].

Metabolic intermediates were measured in neutralized perchloric acid extracts of endothelial cells and, in selected experiments, of human erythrocytes. For preparation of extracts, cell culture dishes were cooled on ice, the monolayers were washed twice with phosphate-buffered saline (PBS, $0.15 \mathrm{~mol} / \mathrm{l}, \mathrm{pH} 7.4$ ), the wash fluid was carefully and completely aspirated and $100 \mu \mathrm{l}$ of chilled $6 \%$ perchloric acid was added to each dish in order to precipitate cellular material, which was harvested with a rubber policeman. On the basis of cell counts obtained from companion dishes, the appropriate number of dishes from each treatment were pooled to yield the desired cell number (at least $4 \times 10^{6}$ endothelial cells for each polyol assay and $20 \times 10^{6}$ cells for each glucose 6-phosphate assay). The harvested material was sonicated and centrifuged. The supernatant was neutralized with $\mathrm{K}_{2} \mathrm{CO}_{3}(2 \mathrm{~mol} / 1)$, the excess salt removed by centrifugation and the supernatant filtered through a $0.45 \mu \mathrm{m}$ membrane. When subjected to high-performance liquid chromatography (HPLC) or gas-liquid chromatography (GLC) the cellular extracts were further purified by application to a column of mixed acidic cation and basic anion exchange resin (Dowex MR-3, Sigma Chemical Co., St.Louis, Mo, USA) and then evaporated under vacuum. Before application to the HPLC column the sample was resuspended in $30 \mu 1$ of HPLC grade water (Fisher Scientific Co., Fair Lawn, NJ, USA). For GLC analysis the sample was resuspended in $200 \mu 1$ of distilled water, dried under nitrogen and derivatized with $50 \mu \mathrm{l}$ of trimethylsilyl reagent (Sigma). When erythrocytes were employed, these were obtained from heparinized blood collected from normal volunteers, washed three times with PBS and incubated in 3 volumes of the same culture medium employed for endothelial cells and containing 5 or $20 \mathrm{mmol} / 1$ glucose. After $4 \mathrm{~h}$ of incubation at $37^{\circ} \mathrm{C}$, erythrocytes were sedimented by centrifugation, washed twice with PBS and aliquots precipitated with 3 volumes of chilled $6 \%$ perchloric acid. The remainder of the extraction procedure was as described above for endothelial cells.

We had chosen to perform sorbitol measurements with the enzymatic method based on the activity of sorbitol dehydrogenase [18] The specificity of sorbitol dehydrogenase (L-iditol: NAD 5-oxidoreductase EC 1.1.1.14 from sheep liver; Sigma) was tested against glucose, galactitol, mannitol, fructose, myoinositol and xylitol (all purchased from Sigma). Reactivity of the enzyme with glycerol is known to be very low [19] and was not checked. As expected [19], all the compounds tested yielded only background readings even at $20 \mu \mathrm{g} /$ $\mathrm{ml}$ concentration, with the exception of xylitol, which reacted in the assay exactly as sorbitol. We thus tested endothelial cells for the presence of measurable amounts of xylitol by enzymatic and chromatographic methods. The enzymatic measurement of xylitol was carried out as previously described [20] employing xylitol: NADP 4-oxidoreductase L-xylulose forming (EC 1.1.1.10 from pigeon liver, Sigma). GLC separation was performed in a Varian Model 3700 Gas Chromatograph on a 3\% SE 30 column (Supelco Inc., Bellefonte, $\mathrm{Pa}$, USA) at a flow rate of $50 \mathrm{ml} / \mathrm{min}$ and temperature increments of $2^{\circ} \mathrm{C} / \min \left(140 \rightarrow 215^{\circ} \mathrm{C}\right)$. HPLC separation was performed in a Spectra-Physics 8700 instrument equipped with a U.V. detector, employing a $300 \times 7.8 \mathrm{~mm}$ Aminex HPX-87 $\mathrm{H}$ organic acid column (Biorad, Richmond, Calif, USA) which was maintained at $40^{\circ} \mathrm{C}$, equilibrated in $30 \%$ buffer $\mathrm{A}\left(10 \mathrm{mmol} / 1 \mathrm{H}_{2} \mathrm{SO}_{4}\right)$ and $70 \%$ buffer $\mathrm{B}$ (purified HPLC water) and eluted in the isocratic mode at a flow rate of $0.5 \mathrm{ml} / \mathrm{min}$. The HPLC effluent was monitored at $195 \mathrm{~nm}$ [21].

The glucose 6-phosphate (G6P) content of cellular extracts was measured spectrophotometrically at $320 \mathrm{~nm}$ by following the reduction of NADP to NADPH in the presence of $50 \mathrm{mmol} / 1$ Tris, $\mathrm{pH} 7.35$ and $1 \mathrm{U}$ of glucose 6-phosphate dehydrogenase (EC 1.1.1.49, Sigma) in a final volume of $0.2 \mathrm{ml}$ [22]. An enzyme blank, all components except the sample, and a sample blank, all components except the enzyme, were included and had an absorbance change that was less than $5 \%$ of the absorbance change of the full mixture.

\section{Statistical analysis}

Data are presented as mean $\pm S D$ in the indicated number of experiments. In each experiment determinations were obtained in duplicate-triplicate. Statisticall analysis was performed by analysis of variance and by linear or polynomial regression (time-course of inhibition of sorbitol accumulation by Sorbinil).

\section{Results}

Since sorbitol dehydrogenase, the enzyme employed to measure cellular sorbitol content, showed substrate cross-reactivity with xylitol, we tested human endothelial cells for the presence of measurable amounts of xylitol. The enzymatic assay based on xylitol:NADP 4-oxidoreductase yielded concentrations of xylitol of $0.20 \pm 0.06 \mathrm{nmol} / 10^{6}$ cells. When, however, the same cellular extracts were tested by GLC or HPLC no xylitol peak was observed. A graphic demonstration of the absence of a xylitol peak in HPLC tracings clearly showing a sorbitol peak is provided in Figure 1. Since the same pattern was evident in GLC separation, we concluded that the enzymatic assay for xylitol was measuring some compound other than xylitol and that in fact, under our culture conditions, human endothelial cells do not accumulate detectable amounts of xylitol. On the basis of the additional specificity studies re- 


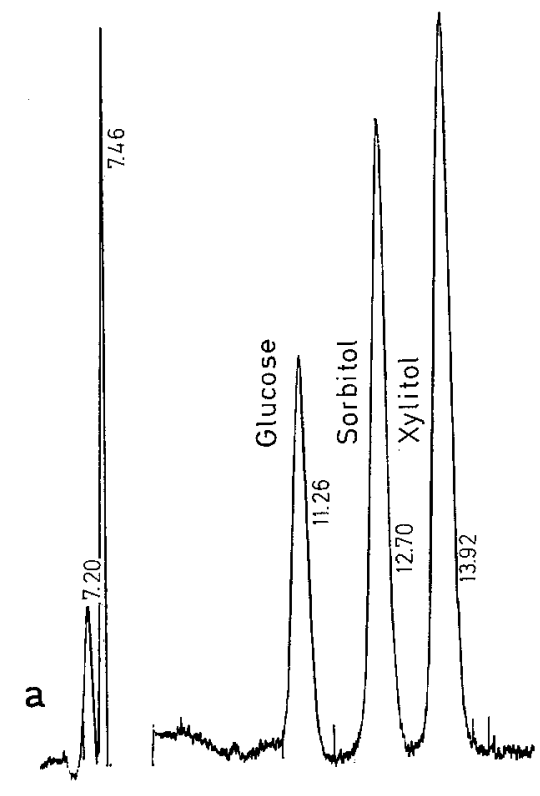

165
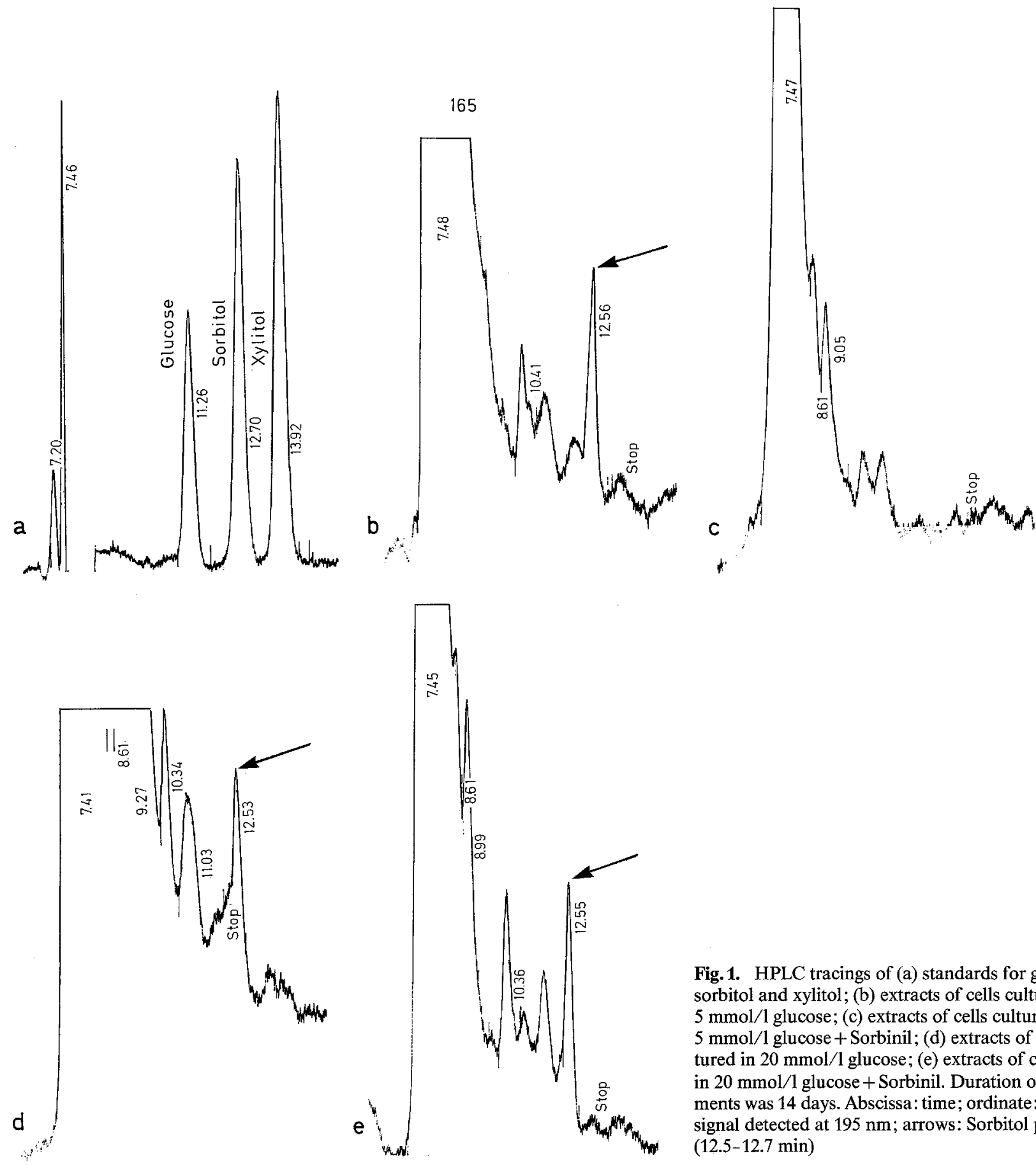

Fig. 1. HPLC tracings of (a) standards for glucose, sorbitol and xylitol; (b) extracts of cells cultured in $5 \mathrm{mmol} / 1$ glucose; (c) extracts of cells cultured in $5 \mathrm{mmol} / 1$ glucose + Sorbinil; (d) extracts of cells cultured in $20 \mathrm{mmol} / 1$ glucose; (e) extracts of cells cultured in $20 \mathrm{mmol} / 1$ glucose + Sorbinil. Duration of all treatments was 14 days. Abscissa: time; ordinate: intensity of signal detected at $195 \mathrm{~nm}$; arrows: Sorbitol peak $(12.5-12.7 \mathrm{~min})$

ported in the Methods section, it could thus be assumed that the readings obtained with sorbitol dehydrogenase quantitatively represented true sorbitol.

Sorbitol accumulation by human endothelial cells in primary culture was quite variable among different batches of cells. In presence of physiologic glucose levels cellular sorbitol content ranged from 0.04 to $0.12 \mathrm{nmol} / 10^{6}$ cells. When cells were exposed to glucose levels mimicking diabetic hyperglycaemia $(20 \mathrm{nmol} / \mathrm{l})$ the sorbitol content increased by $2-$ to 3 -fold to concentrations of $0.08-0.38 \mathrm{nmol} / 10^{6}$ cells $(p<0.01)$.
Addition to the culture medium of $100 \mu \mathrm{mol} / 1$ Sorbinil, an inhibitor of aldose reductase, resulted in a substantial inhibition of sorbitol accumulation by endothelial cells. It was, however, noted (Table 1) that the degree of inhibition achieved varied inversely with the duration of cell exposure to high glucose $(r=-0.957$, $p=0.01$ ). While in cells exposed to high glucose and Sorbinil for $24 \mathrm{~h}$ sorbitol accumulation was inhibited by $71 \%$, in cells exposed for 14 days inhibition was only $14 \%(p<0.01)$. That the declining efficacy of Sorbinil was a function of length of cellular exposure to high glucose and not of loss of inhibitory activity of 
Table 1. Sorbitol accumulation in human endothelial cells exposed to high glucose and effect of an aldose reductase inhibitor (Sorbinil 100 umol/1)

\begin{tabular}{|c|c|c|c|}
\hline $\begin{array}{l}\text { Glucose in medium/ } \\
\text { duration }\end{array}$ & $\begin{array}{l}\text { Sorbinil/ } \\
\text { duration }\end{array}$ & $\begin{array}{l}\text { Sorbitol }^{\mathrm{a}} \\
\text { nmol } / 10^{6} \text { cells } \\
\text { mean } \pm \mathrm{SD}\end{array}$ & $\begin{array}{l}\text { Inhibition } \\
\text { by Sorbinil' }\end{array}$ \\
\hline $\begin{array}{ll}5 \mathrm{mmol} / 1 & 14 \text { days } \\
5 \mathrm{mmol} / 1 & 14 \text { days }\end{array}$ & $\overline{+} 24 \mathrm{~h}$ & $\begin{array}{l}0.053 \pm 0.006 \\
0.006 \pm 0.001\end{array}$ & $89 \%$ \\
\hline $\begin{array}{ll}20 \mathrm{mmol} / 1 & 24 \mathrm{~h} \\
20 \mathrm{mmol} / 1 & 24 \mathrm{~h}\end{array}$ & $\overline{+}+24 \mathrm{~h}$ & $\begin{array}{l}0.100 \pm 0.006 \\
0.029 \pm 0.006\end{array}$ & $71 \%$ \\
\hline $\begin{array}{ll}20 \mathrm{mmol} / 1 & 3 \text { days } \\
20 \mathrm{mmol} / 1 & 3 \text { days }\end{array}$ & $\overline{+} 3$ days & $\begin{array}{l}0.090 \pm 0.02 \\
0.027 \pm 0.01\end{array}$ & $70 \%$ \\
\hline $\begin{array}{ll}20 \mathrm{mmol} / 1 & 8 \text { days } \\
20 \mathrm{mmol} / 1 & 8 \text { days }\end{array}$ & $+\overline{+} 8$ days & $\begin{array}{l}0.086 \pm 0.01 \\
0.036 \pm 0.008\end{array}$ & $59 \%$ \\
\hline $\begin{array}{ll}20 \mathrm{mmol} / 1 & 14 \text { days } \\
20 \mathrm{mmol} / 1 & 14 \text { days }\end{array}$ & $\begin{array}{l}- \\
+14 \text { days }\end{array}$ & $\begin{array}{l}0.082 \pm 0.008 \\
0.071 \pm 0.002\end{array}$ & $14 \%$ \\
\hline
\end{tabular}

Cells were studied for sorbitol content after 12-14 days in culture and

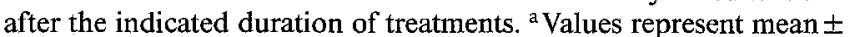
SD of determinations obtained in three experiments. ${ }^{b}$ The correlation coefficient between duration of exposure to high glucose (days) and percent inhibition of sorbitol accumulation by Sorbinil was -0.957 $(p=0.01)$

Table 2. Intracellular accumulation of glucose 6-phosphate in human endothelial cells cultured in high glucose

\begin{tabular}{lll}
\hline Culture conditions & $\begin{array}{l}\text { Glucose 6-phosphate } \\
\text { (nmol/10 cells) }\end{array}$ & \\
\hline $5 \mathrm{mmol} / 1$ glucose & $0.23 \pm 0.11^{\mathrm{a}}$ & \\
$20 \mathrm{mmol} / 1$ glucose & $0.70 \pm 0.08^{\mathrm{a}}$ & $p<0.001$ \\
$20 \mathrm{mmol} / 1$ glucose & $0.21 \pm 0.09^{\mathrm{b}}$ & \\
switched to $5 \mathrm{mmol} / \mathrm{l}$ for $5 \mathrm{~h}$ & &
\end{tabular}

${ }^{a}$ Values represent the mean of 6 experiments $\pm 1 \mathrm{SD}$. ${ }^{\mathrm{b}}$ Values represent the mean of 2 experiments $\pm 1 \mathrm{SD}$

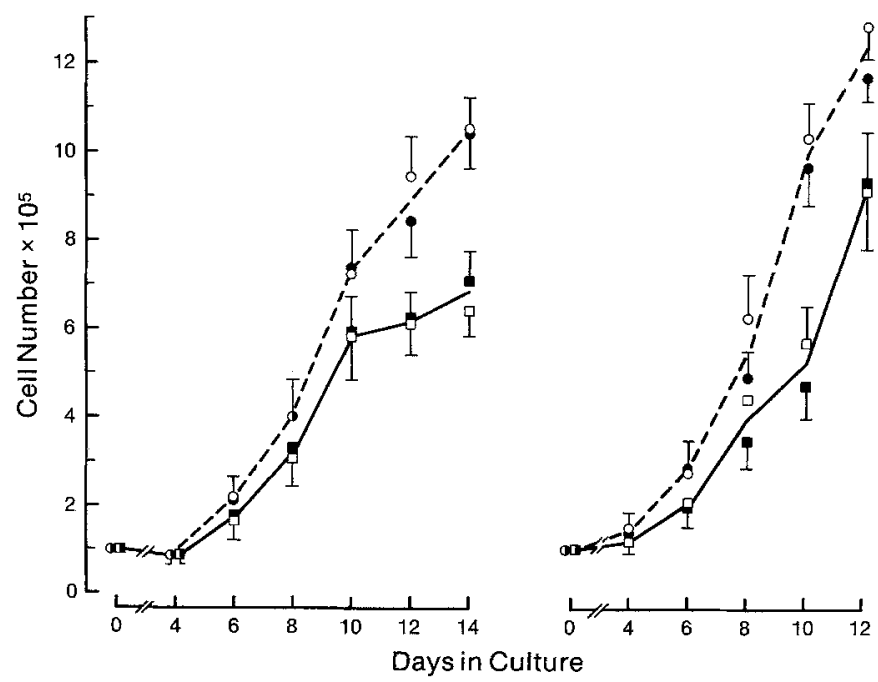

Fig. 2. Sorbinil treatment $(2-10 \mu \mathrm{mol} / 1$ left panel, $100 \mu \mathrm{mol} / 1$ right panel) failed to prevent the proliferative delay observed in human endothelial cells cultured in high glucose $(O$ glucose $5 \mathrm{mmol} / \mathrm{l}$; - glucose $5 \mathrm{mmol} / 1+$ Sorbinil; $\square$ glucose $20 \mathrm{mmol} / 1$; $\square$ glucose $20 \mathrm{mmol} / \mathrm{l}+$ Sorbinil) Each point represents the mean \pm SD of the determinations obtained in five experiments. The proliferation curves of cells exposed to $20 \mathrm{mmol} / 1$ glucose in presence or absence of Sorbinil are significantly different $(p<0.005$ by ANOVA) from those of cells exposed to $5 \mathrm{mmol} / 1$ glucose the drug was verified in two ways. First, we compared the effect of freshly prepared Sorbinil versus Sorbinil incubated with endothelial cell cultures for three days (the maximum interval between medium changes) on the accumulation of sorbitol by human erythrocytes (RBC). Sorbitol content of RBC incubated for $3 \mathrm{~h}$ at $37^{\circ} \mathrm{C}$ in presence of $5 \mathrm{mmol} / 1$ glucose was $7.7 \pm$ $2.6 \mathrm{nmol} / \mathrm{ml} \mathrm{RBC}$ and increased to $14.6 \pm 0.9 \mathrm{nmol} / \mathrm{ml}$ $\mathrm{RBC}$ in presence of $20 \mathrm{mmol} / 1$ glucose. The addition of Sorbinil reduced this amount to $8.8 \pm 0.8 \mathrm{nmol} / \mathrm{ml}$ $\mathrm{RBC}$ (fresh Sorbinil) and to $8.4 \pm 0.3 \mathrm{nmol} / \mathrm{ml} \mathrm{RBC}$ (incubated Sorbinil). Second, we contrasted the effects of chronic Sorbinil treatment (14 days) on sorbitol accumulation by cultures exposed to 5 or $20 \mathrm{mmol} / 1 \mathrm{glu}$ cose for 14 days (Fig.1). While the HPLC tracing of cells cultured in $5 \mathrm{mmol} / 1$ glucose showed, in the presence of Sorbinil, obvious disappearance of the sorbitol peak, the latter was practically unmodified in cells cultured in $20 \mathrm{mmol} / \mathrm{l}$ glucose in the presence of Sorbinil. No attempts at quantitation of sorbitol were made in these experiments, in which the amount of cellular extracts derived from the $5 \mathrm{mmol} / 1$ glucose cultures was maximized in order to ensure a detectable sorbitol signal.

We had previously documented [7] that in endothelial cell cultures exposed to $20 \mathrm{nmol} / 1$ glucose the achievement of saturation density is substantially delayed, with cell counts throughout the growth curve being $70-80 \%$ of control. We thus investigated whether the reduction in sorbitol content achieved with Sorbinil would modify the proliferative delay induced by exposure to high glucose. As illustrated in Figure 2, none of the concentrations of Sorbinil tested $(2-100 \mu \mathrm{mol} / 1)$ succeeded in modifying the hindering effects of high glucose on endothelial cell proliferation. Both in the presence or absence of Sorbinil the growth curve of the cultures exposed to high glucose differed significantly from control $(p<0.005)$.

The intracellular accumulation of glucose 6-phosphate (Table 2) was enhanced 3-fold in endothelial cells cultured in high glucose: $0.70 \pm 0.08 \mathrm{nmol} /$ $10^{6}$ cells versus $0.23 \pm 0.11$ in controls $(p<0.001)$. In order to exclude that the increased G6P found in high glucose cultures might be contributed by G6P released from cell membranes during the preparation of extracts, we measured G6P in extracts of endothelial cells that - after having been chronically exposed to $20 \mathrm{mmol} / 1$ glucose - were switched to culture medium containing $5 \mathrm{mmol} / 1$ glucose for $5 \mathrm{~h}$. The content of G6P in these cells (Table 2) was the same as in cells chronically exposed to $5 \mathrm{mmol} / \mathrm{l}$ glucose, thus excluding that G6P detected in extracts of cells cultured in high glucose could derive from dissociation of the sugar from adducts possibly formed with cellular constituents. When reported to cellular protein content ( $\cong 200 \mu \mathrm{g} / 10^{6}$ cells) the amount of G6P found in endothelial cells was substantially higher than that reported in the literature for human erythrocytes $(\cong 30 \mathrm{nmol} / \mathrm{ml}$ 
$\mathrm{RBC}, 1 \mathrm{ml} \mathrm{RBC}=371 \mathrm{mg}$ protein). We thus tested the accuracy of our assay procedure by measuring G6P content in human RBC. The G6P content of RBC incubated for $3 \mathrm{~h}$ in $5 \mathrm{mmol} / 1$ glucose was $39 \pm$ $5 \mathrm{nmol} / \mathrm{ml} \mathrm{RBC}$, and is in good agreement with published data $[23,24]$.

\section{Discussion}

Abnormalities of function and structure of vascular endothelium are likely to represent a central pathogenetic event in the development of diabetic angiopathy [1-6], and clarification of the mechanisms of endothelial cell injury should assist in developing rational strategies for clinical intervention. Although the tissue culture environment is quite remote from the complex and dynamic in vivo milieu, it offers the opportunity to study vascular endothelial cells of human origin not otherwise readily accessible.

We have previously shown $[7,8]$ that human endothelial cells in primary culture are susceptible to "glucose toxicity" as manifested by the occurrence of accelerated death, decreased replication and DNA damage upon exposure to high glucose concentrations. The combined results obtained in this and other studies indicate that the polyol pathway is not of major importance in mediating the ill effects of high glucose observed in this model. The amount of intracellular sorbitol accumulated in the presence of high glucose in good agreement with previous observations [25] was two orders of magnitude below that expected to possibly increase intracellular osmotic pressure [10]. It could be argued that measurements of intracellular sorbitol content might grossly underestimate sorbitol production if leakage of the metabolite to the medium is substantial. From studies in other tissues it is, however, apparent that, when production of sorbitol is high, this continues to be mirrored in the intracellular sorbitol content in spite of obvious signs of cellular leakage [26].

A more important consideration is that intracellular sorbitol content does not in itself reflect other possible ill effects of enhanced polyol pathway activity, the best recognized of which is compromised energy balance secondary to myoinositol depletion [11]. In various tissues $[11,26,27]$ such ill effects have uniformly been prevented by Sorbinil treatment. In human endothelial cells, however, treatment with Sorbinil failed to improve even slightly the proliferative delay induced by high glucose, despite reducing cellular sorbitol content to concentrations below control levels throughout a good portion of the growth curve. Moreover, a major role for myoinositol depletion in the replicative delay of human endothelial cells exposed to high glucose has been specifically excluded by studies involving supplementation of the culture medium with supraphysiologic concentrations of myoinositol [28].
It cannot be determined from these studies whether the minimal extent of polyol pathway activation by high glucose is a function of tissue culture conditions, type of endothelial cells studied or human origin of the cells. The latter characteristic is, however, likely to be important, since vascular endothelial cells of the human retina do not stain for aldose reductase [29], and aldose reductase from other human tissues (lens) shows a higher $\mathrm{km}$ for glucose than the enzyme present in other species [30].

Exposure of endothelial cells to Sorbinil uncovered an aspect of Sorbinil action of potential relevance to its clinical applications. This was the progressively lesser inhibition of sorbitol formation achieved by Sorbinil with increasing time of exposure of endothelial cells to high glucose. Since the phenomenon could not be ascribed to diminished intrinsic potency of the drug, it may represent a consequence of the "activation" of human aldose reductase. Das and Srivastava have shown [31] that, in human tissues chronically exposed to high glucose, aldose reductase changes its kinetic properties and becomes less sensitive than in its native form to inhibition by various drugs, including Sorbinil. Together with the low activity of the polyol pathway in human tissues this phenomenon may contribute to the difficulties in establishing a clear-cut effectiveness of aldose reductase inhibitors in the treatment of diabetic complications in humans.

In spite of the saturation kinetics of hexokinase, accumulation of glucose 6-phosphate (G6P) appears to be a common occurrence in tissues obtained from diabetic humans or animals; the phenomenon can be ascribed to the relief by high ambient glucose of the G6P inhibition of hexokinase [24]. The amount of G6P found in endothelial cells cultured in physiologic glucose was almost an order of magnitude above that reported for erythrocytes [23], brain [13] and kidney [32], but superimposable to that found in rat myocardium [33]. The high G6P content of endothelial cells could not be attributed to inaccuracy in the assay nor to release of G6P from possible adducts; it is unclear at this time whether it represents a tissue-related characteristic (as in myocardium) or a consequence of the in vitro incubation conditions. Nevertheless, the almost 3-fold increase in G6P observed upon exposure to high glucose indicates that endothelial cells respond akin other tissues to ambient glucose levels. Owing to its open ring structure G6P is a powerful "glycosylator", ten times as potent as glucose on a molar basis $[14,15]$. Additionally, reducing sugars have been shown to undergo auto-oxidation in aqueous milieu with consequent generation of free radicals and intermediates of dioxygen reduction, and, albeit less potent than other monosaccharides, G6P is also in this respect more potent than glucose [34]. Thus, either through non enzymatic glycosylation or through free radicals production, accumulation of $\mathrm{G} 6 \mathrm{P}$ might damage intracellular constituents and, among them, nucleic acids $[35,36]$. We are particularly interested in exploring 
this possibility to explain the replicative delay $[7,9]$ and DNA damage [8] observed in vascular endothelial cells maintained in a high glucose milieu, since these abnormalities could conceivably be prodromes of the decreased endothelial cell density [2] or accelerated disappearance $[5,6]$ described in the diabetic state.

Acknowledgements. We are indebted to Dr. N.J.Hutson of Pfizer Center Research for supplying the Sorbinil, to Dr. A. Barrieux for helpful discussions, and to L. Shull for editorial assistance. This work was supported by grants from the Charles E. Culpeper Foundation, the American Diabetes Association (Southern California Affiliate), the American Heart Association (California Affiliate) and the Upjohn Company.

\section{References}

1. Cunha-Vaz JG (1983) Studies on the pathophysiology of diabetic retinopathy. Diabetes 32 [Suppl 2]: 20-27

2. Dolgov VV, Zaikina OE, Bondarenko MF, Repin VS (1982) Aortic endothelium of alloxan diabetic rabbits: a quantitative study using scanning electron microscopy. Diabetologia 22: 338-343

3. Parving H-H (1976) Increased microvascular permeability to plasma proteins in short- and long-term juvenile diabetics. Diabetes 25 [Suppl 2]: 884-889

4. Lorenzi M, Healy DP, Hawkins R, Printz JM, Printz MP (1986) Studies on the permeability of the blood-brain barrier in experimental diabetes. Diabetologia 29: 58-62

5. Cogan DG, Toussaint D, Kuwabara T(1961) Retinal vascular patterns. Arch Ophthalmol 66:366-378

6. Tilton RG, Faller AM, Burkhardt JK, Hoffmann PL, Kilo C, Williamson JR (1985) Pericyte degeneration and acellular capillaries are increased in the feet of human diabetic patients. Diabetologia 28: 895-900

7. Lorenzi M, Cagliero E, Toledo S (1985) Glucose toxicity for human endothelial cells in culture: delayed replication, disturbed cell cycle, and accelerated death. Diabetes 34: 621 -627

8. Lorenzi M, Montisano D, Toledo S, Barrieux A (1986) High glucose induces DNA damage in cultured human endothelial cells. $J$ Clin Invest 77: 322-325

9. Capetandes A, Gerritsen ME (1986) The effects of elevated glucose concentration on cultured bovine retinal endothelial (BRE) cells. Fed Proc 45: 460 (Abstract)

10. Gabbay KH (1973) The sorbitol pathway and the complications of diabetes. N Engl J Med 288: 831-836

11. Greene DA, Lattimer SA (1984) Action of sorbinil in diabetic peripheral nerve: relationship of polyol (sorbitol) pathway inhibition to a myoinositol-mediated defect in sodium-potassium ATPase activity. Diabetes 33: 712-716

12. Brownlee M, Vlassara H, Cerami A (1984) Nonenzymatic glycosylation and the pathogenesis of diabetic complications. Ann Intern Med 101: 527-537

13. Thurston JH, Hauhart RE, Jones EM, Ater JA (1975) Effects of alloxan diabetes, anti-insulin serum diabetes, and non-diabetic dehydration on brain carbohydrate and energy metabolism in young mice. J Biol Chem 250: 1751-1758

14. Stevens VJ, Rouzer CA, Monnier VM, Cerami A (1978) Diabetic cataract formation: potential role of glycosylation of lens crystallins. Proc Natl Acad Sci USA 75: 2918-2922

15. Brownlee M, Vlassara H, Cerami A (1983) Nonenzymatic glycosylation reduces the susceptibility of fibrin to degradation by plasmin. Diabetes 32: 680-684

16. Lorenzi M, Cagliero E, Markey B, Henriksen T, Witztum JL, Sampietro T (1984) Interaction of human endothelial cells with elevated glucose concentrations and native and glycosylated low density lipoproteins. Diabetologia 26: 218-222
17. Kinoshita JH, Fukushi S, Kador P, Merola LO (1979) Aldose reductase in diabetic complications of the eye. Metabolism 28: 462-469

18. Malone JI, Knox G, Benford S, Tedesco TA (1980) Red cell sorbitol, an indicator of diabetic control. Diabetes 29: 861-864

19. Bergmeyer HU, Gruber W, Gutmann I (1974) D-sorbitol. In: Methods of enzymatic analysis. Academic Press, New York London, Verlag Chemie Weinheim, pp 1323-1326

20. Travis SF, Morrison AD, Clements RS, Jr, Winegrad AI, Oski FA (1971) Metabolic alterations in the human erythrocyte produced by increases in glucose concentration: the role of the polyol pathway. J Clin Invest 50:2104-2112

21. Lohmander LS (1986) Analysis by high-performance liquid chromatography of radioactively labeled carbohydrate components of proteoglycans. Anal Biochem 154: 75-84

22. Cooper J, Srere PA, Tabachnick M, Racker E (1958) The oxidative pentose phosphate cycle. II. Quantitation and determination of intermediates and enzymes. Arch Biochem Biophys 74: 306-314

23. Stevens VJ, Vlassara H, Abati A, Cerami A (1977) Nonenzymatic glycosylation of hemoglobin. J Biol Chem 252: 2998-3002

24. Fujii S, Beutler E (1985) High glucose concentrations partially release hexokinase from inhibition by glucose 6-phosphate. Proc Natl Acad Sci USA 82: 1552-1554

25. Olgemoller B, Schon J, Wieland OH (1985) Endothelial plasma membrane is a glucocorticoid-regulated barrier for the uptake of glucose into the cell. Mol Cell Endocrinol 43: 165-171

26. Gonzalez A-M, Sochor M, McLean P (1983) The effect of an aldose reductase inhibitor (Sorbinil) on the level of metabolites in lenses of diabetic rats. Diabetes 32: 482-485

27. MacGregor LC, Matschinsky FM (1985) Treatment with aldose reductase inhibitor or with myo-inositol arrests deterioration of the electroretinogram of diabetic rats. J Clin Invest 76: 887-889

28. Lorenzi M, Toledo S (1986) Myoinositol enhances the proliferation of human endothelial cells in culture but fails to prevent the delay induced by high glucose. Metabolism 35: 824-829

29. Akagi Y, Yajima Y, Kador PF, Kuwabara T, Kinoshita JH (1984) Localization of aldose reductase in the human eye. Diabetes 33 : $562-566$

30. Jedziniak JA, Chylack LT, Jr, Cheng H-M, Gillis MK, Kalustian AA, Tung WH (1981) The sorbitol pathway in the human lens: aldose reductase and polyol dehydrogenase. Invest Ophthalmol Vis Sci 20: $314-326$

31. Das B, Srivastava SK (1985) Activation of aldose reductase from human tissues. Diabetes 34: 1145-1151

32. Steer KA, Sochor M, McLean P (1985) Renal hypertrophy in experimental diabetes: changes in pentose phosphate pathway activity. Diabetes 34: 485-490

33. Chen V, Ianuzzo CD, Fong BC, Spitzer JJ (1984) The effects of acute and chronic diabetes on myocardial metabolism in rats. Diabetes 33: 1076-1084

34. Thornalley P, Wolff S, Crabbe J, Stern A (1984) The autoxidation of glyceraldehyde and other simple monosaccharides under physiological conditions catalysed by buffer ions. Biochim Biophys Acta 797: 276-287

35. Bucala R, Model P, Cerami A (1984) Modification of DNA by reducing sugars: a possible mechanism for nucleic acid aging and age-related dysfunction in gene expression. Proc Natl Acad Sci USA 81 : 105-109

36. Morita J, Ueda K, Nanjo S, Komano T (1985) Sequence specific damage of DNA induced by reducing sugars. Nucleic Acids Res 13: $449-458$

Received: 26 May 1986

and in revised form: 4 February 1987

Dr. Mara Lorenzi

U.C.S.D. Medical Center (H-811-C)

225 Dickinson Street

San Diego, California 92103

USA 